\title{
QTL studies reveal little relevance of chilling-related seedling traits for yield in maize
}

\author{
Journal Article \\ Author(s): \\ Leipner, Jörg; Jompuk, Choosak; Camp, Karl-Heinz; Stamp, Peter; Fracheboud, Yvan \\ Publication date: \\ 2008 \\ Permanent link: \\ https://doi.org/10.3929/ethz-b-000010056 \\ Rights / license: \\ In Copyright - Non-Commercial Use Permitted \\ Originally published in: \\ Theoretical and Applied Genetics 116(4), https://doi.org/10.1007/s00122-007-0690-2
}




\title{
QTL studies reveal little relevance of chilling-related seedling traits for yield in maize
}

\author{
Jörg Leipner · Choosak Jompuk · Karl-Heinz Camp • \\ Peter Stamp · Yvan Fracheboud
}

Received: 22 May 2007 / Accepted: 28 November 2007 / Published online: 9 January 2008

(C) Springer-Verlag 2008

\begin{abstract}
Prolonged low temperature phases and shortterm cold spells often occur in spring during the crucial stages of early maize (Zea mays L.) development. The effect of low temperature-induced growth retardation at the seedling stage on final yield is poorly studied. Therefore, the aim was to identify genomic regions associated with morpho-physiological traits at flowering and harvest stage and their relationship to previously identified quantitative trait loci (QTLs) for photosynthesis and morpho-physiological traits from the same plants at seedling stage. Flowering time, plant height and shoot biomass components at harvest were measured in a dent mapping population for cold tolerance studies, which was sown in the Swiss Midlands in early and late spring in two consecutive years. Early-sown plants exhibited chilling stress during seedling stage, whereas late-sown plants grew under favorable conditions. Significant QTLs, which were stable across environments, were found for plant height and for the time of flowering. The QTLs for flowering were frequently co-localized with QTLs for plant height or ear dry weight. The comparison
\end{abstract}

Communicated by H. H. Geiger.

J. Leipner $(\bowtie) \cdot$ C. Jompuk · P. Stamp · Y. Fracheboud

Institute of Plant Sciences, ETH Zurich,

Universitätstrasse 2, 8092 Zurich, Switzerland

e-mail: joerg.leipner@ipw.agrl.ethz.ch

K.-H. Camp

Delley Samen und Pflanzen AG (DSP), Case postale 16, 1567 Delley, Switzerland

Present Address:

C. Jompuk

Department of Agronomy, Faculty of Agriculture,

Kasetsart University, Kamphaeng Saen Campus,

73140 Nakhon Pathom, Thailand with QTLs detected at seedling stage revealed only few common QTLs. A pleiotropic effect was found on chromosome 3 which revealed that a good photosynthetic performance of the seedling under warm conditions had a beneficial effect on plant height and partially on biomass at harvest. However, a high chilling tolerance of the seedling seemingly had an insignificant or small negative effect on the yield.

\section{Introduction}

Maize (Zea mays L.) is a crop from the (sub) tropics but was cultivated at higher geographic latitudes in America already before the New World was discovered. Early North-American flint populations were introduced to Central Europe shortly afterwards (Rebourg et al. 2003; Revilla et al. 2003). However, maize of the dent type is still characterized by a low chilling tolerance (Dolstra et al. 1988). In particular, it is essential to maximize the yield potential of maize under a combination of suboptimal temperature and moderately high light intensity. Adaptation to such marginal growth conditions has been successful due to breeding for early maturing maize plants, compromising between the risk of yield loss and an acceptable level of yield gain (Stamp 1986). In the temperate regions, suboptimal temperatures occurring during spring affect seedling establishment and photosynthesis (Stirling et al. 1991; Leipner et al. 1999). They preclude early sowing, so that at high-latitude, flowering and grain filling occur when both radiation and temperature are declining, which can affect yield potential (Otegui and Bonhomme 1998). Furthermore, drought occurs frequently around flowering which is a critical period for grain set (c.f. Hall et al. 1981). Therefore, maize with improved chilling tolerance could be sown earlier, 
resulting in a better fit between crop cycle and availability of natural resources.

Although the beneficial effects of a high chilling tolerance on early vigor is widely recognized, its effect on the further plant development and finally on the yield is less clear. Few studies indicate that seedling development has indeed an effect on grain yield. For example, transplanting experiments in southern England revealed that in cool years yield was higher when seedlings were raised for some days under more favorable conditions in greenhouses as compared to field-sown plants (Dale and Drennan 1997). Recently, Chenu et al. (2007) showed that organ growth and development was affected during the whole plant cycle by low temperature although the cold period was limited to the first stages of maize development. Therefore, improvement of chilling tolerance of maize seedlings is a desirable aim for a more stable and higher crop yield. However, Greaves (1996) points out that improving a single suboptimal temperature tolerance trait per se may not influence the yield performance of a particular genotype in a temperature-limiting environment. Rather the combination of multiple tolerance traits might allow a better performance throughout the growing season resulting finally in a higher yield.

In order to unravel the interaction of such complex traits, quantitative trait loci analysis has become a useful tool for plant physiologists and breeders (Vreugdenhil et al. 2007). Extensive genome mapping of maize based on DNA markers has been accomplished. These maps and their associated technology have been used successfully for a number of quantitative trait loci (QTL) analyses. A number of papers deal with the chilling tolerance of maize seedlings (Fracheboud et al. 2002, 2004; Hund et al. 2005; Jompuk et al. 2005; Pimentel et al. 2005; Presterl et al. 2007). Once the significance of these QTLs for chilling tolerance has been verified, it should become possible to pyramiding the favorable alleles into elite germplasm through marker-assisted selection (MAS).

Using a method based on chlorophyll fluorescence measurements, we have developed a set of inbred lines with contrasting chilling tolerance of photosynthesis (Fracheboud et al. 1999). Since these lines were selected solely on the basis of chilling tolerance of photosynthesis they are a unique material to identify genetic loci associated with chilling tolerance of photosynthesis by QTL analysis. In previous studies, we have examined this material in respect to chilling tolerance at the seedling stage under controlled conditions (Fracheboud et al. 2004) and in the field (Jompuk et al. 2005). These studies revealed major QTLs for chilling tolerance of photosynthesis which were stable across cold environments. Furthermore, consistent QTLs for biomass accumulation and for photosynthesis under warm conditions were identified.
The aim of this study was to elucidate the relevance of chilling tolerance of seedlings for yield-related traits. Studies investigating the effect of chilling tolerance of maize seedlings on the grain yield were conducted with individual genotypes (Mock and McNeill 1979) or hybrids (Revilla et al. 2000). So far, there are no studies in term of QTL for chilling stress during seedling stage and its relation to the biomass yield at harvest. We hypothesized that if chilling tolerance at seedling stage has a beneficial effect on maize yield then common QTLs for chilling tolerance at seedling stage and for yield-related traits at harvest will be found. In order to corroborate this, a QTL analysis was conducted in a segregating $F_{2: 3}$ population grown in the field; flowering and yield-related traits were determined. The QTLs for these traits were compared with QTLs for photosynthesisrelated traits and for growth parameters obtained from the same plants during early development under low temperature (Jompuk et al. 2005).

\section{Materials and methods}

\section{Plant material}

A dent maize (Zea mays L.) mapping population in the $F_{2: 3}$ generation, consisting of 226 families derived from the cross ETH-DH7 and ETH-DL3, was used in the present QTL experiment (for details, see Fracheboud et al. 2004). The source material was derived from the actual breeding population of the Swiss DSP (Delley Samen und Pflanzen AG, Delley, Switzerland). The parental lines of the population are characterized by a contrasting chilling-tolerance of photosynthesis and were obtained by a divergent selection from a Swiss dent maize breeding population using the chlorophyll fluorescence parameter $\phi_{\text {PSII }}$ (quantum efficiency of PSII) as selection criteria (Fracheboud et al. 1999).

\section{Field experiments}

The field experiments were conducted at the experimental station of the Institute of Plant Sciences of the ETH in Eschikon near Zurich, Switzerland $\left(47^{\circ} 26^{\prime} \mathrm{N}, 8^{\circ} 40^{\prime} \mathrm{E}\right.$, $550 \mathrm{~m}$ a.s.l.). In 2002, the $F_{2: 3}$ population was sown on 26 April (early sowing) and 24 May (late sowing). In 2003, sowing was done on 14 April (early) and 15 May (late) (see also Jompuk et al. 2005). Fertilization was applied according to good agricultural practice. The $\mathrm{N}$ fertilization $\left(\mathrm{NH}_{4} \mathrm{NO}_{3}\right)$ was $115 \mathrm{~kg} \mathrm{ha}^{-1}$ and was split into two applications at the 3- and 6-leaf stage. Weeds were controlled by a combination of atrazin, sulcotrion and nicosulfuron.

The experiments were over-sown by machine and thinned to the final plant number of $13 \mathrm{~m}^{-2}$ after emergence. The experimental unit was a single-row plot with 50 plants, $5 \mathrm{~m}$ 
long, and $0.75 \mathrm{~m}$ between the rows. Trials of the $226 F_{2 \cdot 3}$ lines were conducted using an alpha $(0,1)$ lattice design with 23 blocks per replication (Patterson and Williams 1976) and two replications for each sowing date. Each replication was bordered by two rows of a mixture of the $F_{2: 3}$ lines. In each experimental unit, the first two plants were not used for measurements. The soil was a Eutric Cambisol (FAO classification) with a clay loam (CL) texture and a low content of organic matter (3\%) (Richner et al. 1996). Meteorological data were recorded at 15-min intervals, $2 \mathrm{~m}$ above the soil surface.

\section{Morpho-physiological traits}

Female and male flowering was defined as the number of days from sowing to the day when half of the plants from each experimental unit showed the female flower and began to shed pollen, respectively. The plant height was determined from ten plants per experimental unit before harvest. The dry weight at final harvest was determined from ten plants. The shoot of the plants was cut at ground level; ears without husk leaves and the remaining plant (straw) were separately shopped by machine. Aliquots of samples were oven dried at $90^{\circ} \mathrm{C}$ for at least $72 \mathrm{~h}$.

\section{Statistical analysis and QTL mapping}

The broad-sense heritability $\left(h^{2}\right)$ was estimated over the 2 years as described by Hallauer and Miranda (1981). Confidence intervals of heritability were calculated according to Knapp et al. (1985).

As input for the QTL analyses, adjusted means of the trait values were calculated by the program Alphagen version 2.3 (Scottish Agricultural Statistics Service, Edinburgh). The QTL analyses were performed using the program QTL Cartographer version 1.17b (Basten et al. 2005). The method of composite interval mapping, model 6 of the Zmapqtl program module of QTL Cartographer, was deployed for mapping the QTLs (Basten et al. 1994). Joint analyses of the phenotypic data from multiple environments by composite interval mapping were computed with the JZmapqt procedure of QTL Cartographer (Jiang and Zeng 1995). In both cases, the genome was scanned at 2cM intervals, and the window size was set at $30 \mathrm{cM}$. Cofactors were chosen using the forward-backward method of step-wise regression at $p\left(F_{\text {in }}\right)=p\left(F_{\text {out }}\right)=0.05$. The presence of a QTL was declared significant when the likelihood of odds (LOD) value was higher than 3.5 for a single-environment analysis and higher than 6.0 for the joint analysis of four environments. These values correspond to a Type-I error rate ( $\alpha$ level) of 0.021 , assuming that all the chromosome arms segregate independently. Additive effects of the detected QTLs were estimated by the Zmapqt procedure of $Q T L$ Cartographer; the $R^{2}$ value (coefficient of determina- tion) from this analysis indicated the percentage of phenotypic variance explained by marker genotypes at the locus.

\section{Results}

\section{Environmental effects}

The two experimental years were characterized by different climatic conditions throughout the experimental phases (Fig. 1). In both years, seedlings of the early-sown set developed under a much lower temperature than the latesown plants (see also Jompuk et al. 2005). In general, the growing season of 2002 was cooler than 2003. The average daily temperature of July and August 2002 and, in particular, of September 2002 was below the long-standing average (MeteoSchweiz, http://www.meteoschweiz.ch). However, the temperature in June 2002 was considerably above this average. The climatic conditions of 2003 were characterized by very high temperatures and low precipitation. In 2003, the warmest June since beginning of recording in 1753 was measured for Switzerland. Furthermore, the meteorological summer of 2003 was one of the ten driest in the region of Eschikon (station Zurich) since 1900 (MeteoSchweiz, http://www.meteoschweiz.ch).

The time from sowing until flowering reflected the different climatic conditions. In 2003, the time until male flowering was in average 12 days (early sowing) and 6 days (late sowing) shorter than in 2002 (Table 1). The time until male flowering of late-sown $F_{2: 3}$ plants was 14 days (in 2002) and 7 days (in 2003) shorter than the one of earlysown plants. The contrasting climatic conditions were also reflected in the time until maturation, which was about 10 days shorter in early-sown plants in 2003 than in 2002. In 2002, plants of the late-sown set had to be harvested before the black layer of the seeds was fully developed. Consequently, shoot dry weight was considerably lower in the late-sown set of 2002 as compared to the other sets (Table 1). Differences between the years were also found in respect to the proportion of the ear weight on the shoot weight; it was significantly lower in 2003 than in 2002 (data not shown). The high influence of the climatic conditions on the time until flowering as well as on the ear and shoot dry weight was also reflected in a low heritability for these traits (Table 1). The plant height was characterized by a high heritability and, consequently, there was only a small effect of years and sowing dates on plant height.

\section{Quantitative trait loci analysis}

The joint QTL analysis, combining data of the four environments, revealed several chromosomal regions, which were associated with the time of flowering, plant height and 

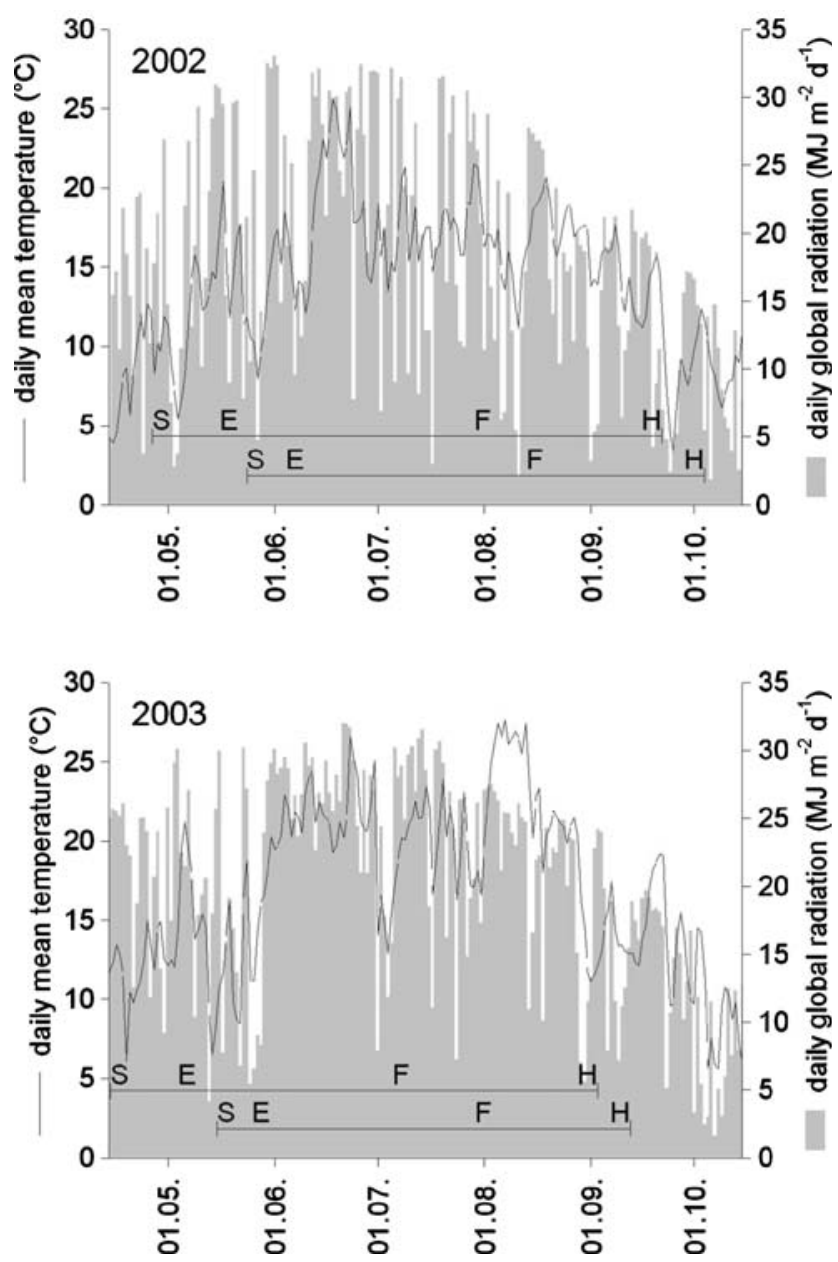

Fig. 1 Daily means temperature and daily global radiation during the growing season in Eschikon in 2002 and 2003. S, E, $F$ and $H$ indicate sowing date, emergence, flowering and harvest, respectively

biomass at harvest. For the date of male flowering, two QTLs were detected (Table 2). These QTLs were located on chromosomes $1(13 \mathrm{cM})$ and $9(50 \mathrm{cM})$ and were found for the date of female flowering as well. Both QTLs were characterized by high LOD scores in 2002 but not in 2003, with the exception of the QTL at chromosome 9 which was significant in the early set of 2003. Plants, which inherited the chromosomal region from ETH-DH7 at these positions, flowered later in 2002 but earlier in 2003. For female flowering date, three additional QTLs were detected on chromosomes $5(72 \mathrm{cM})$ and $7(27$ and $110 \mathrm{cM})$. Again, these QTLs were highly significant in 2002 but below the threshold in 2003.

For plant height, a large number of QTLs were detected. The high heritability for this trait was reflected in a high stability of most of the QTLs across environments (Table 2). In particular, the QTL on chromosome 3 $(108 \mathrm{cM})$ was very stable across sowing dates and years. Four more QTLs, which were little affected by the environment and which were characterized by high LOD scores were localized on chromosome 1 (4 and $105 \mathrm{cM})$, beginning of chromosome 5 and on chromosome $6(56 \mathrm{cM})$. The allele of ETH-DL3 was responsible for an increased plant height concerning the QTLs on chromosomes $1(105 \mathrm{cM})$, $3(0$ and $108 \mathrm{cM}), 5$ and 8 .

Shoot dry matter at harvest was dissected into two parts: ear dry weight and straw dry weight. The number of QTLs for the traits at harvest was rather low. The joint analysis revealed one QTL, on chromosome 7 at about $31-36 \mathrm{cM}$, which was detected for shoot weight and its components straw and ear dry weight; it was strongest in the late sown set of 2003 (Table 2). The allelic contribution for high shoot, straw, and ear dry weight at this QTL came from ETH-DH7, the cold-tolerant parent.

Since climatic conditions were considerably different between the four environments, QTL analyses at individual environments were conducted as well. Additionally to the QTLs revealed by the joint analyses, further QTLs were found in particular for trait data from 2002. For this data set, QTLs were identified for straw dry weight on chromosome 2 (about $130 \mathrm{cM}$ ), for ear, straw and shoot dry weight on chromosome $9(49-88 \mathrm{cM})$ and for shoot dry weight on the beginning of chromosome 10 (Fig. 2). Furthermore, a common QTL was identified for shoot, straw and ear dry weight at chromosome $6(50 \mathrm{cM})$ in the early-sown plants of 2002 whose favorable allele was inherited from ETHDH7. In 2003, QTLs were found for shoot and straw dry weight (early-sown in 2003) on chromosome 2 (235 cM) and for ear and shoot dry weight (late-sown in 2003) at $84 \mathrm{cM}$ on chromosome 10 (Fig. 2).

Comparison with QTLs for seedling traits

In order to examine the effect of seedling vigor on the yield, the QTL data of the present study were compared with those identified at the seedling stage in the same experiments (Jompuk et al. 2005). Due to high $\mathrm{Q} \times \mathrm{E}$ interaction for most of the QTLs, the QTL analyses were conducted for individual environments. These analyses revealed the presence of overlapping QTLs on chromosomes 2, 3 and 10 (Fig. 2). The QTL for the operating quantum efficiency of PSII $\left(\phi_{\text {PSII }}\right)$ and for leaf greenness (SPAD) identified previously near the centromer of chromosome 2 in seedlings of the early-sown set (Jompuk et al. 2005), mapped close to a QTL for straw dry weight in 2002. However, the additivity of this QTL at seedling stage was positive while it was negative for straw dry weight. Similarly, an overlapping QTL with contrasting additivity was found in the late-sown set in 2003 on chromosome 10 for SPAD at seedling stage (positive additivity) and ear and shoot dry weight (negative additivity). The region close to marker mmc0022 on chromosome 3 harbored QTLs for leaf greenness and shoot dry weight of the seedlings as well as for straw and shoot 
Table 1 Summary statistics including means, variances $\left(\sigma_{\mathrm{g}}^{2}\right.$ and $\left.\sigma_{\mathrm{ge}}^{2}\right)$ and heritability $\left(h^{2}\right)$ for flowering traits, plant height at flowering and straw, ear, and shoot dry weight at harvest of the $F_{2: 3}$ families

\begin{tabular}{|c|c|c|c|c|c|c|c|c|}
\hline Trait & Year & Env. & Mean \pm SD & Minimum & Maximum & $\sigma_{\mathrm{g}}^{2}$ & $\sigma_{\mathrm{ge}}^{2}$ & $h^{2}(95 \%$ C.I. $)$ \\
\hline \multirow[t]{4}{*}{ Male flowering (days after sowing) } & \multirow[t]{2}{*}{2002} & $\mathrm{E}$ & $94.9 \pm 2.1$ & 86 & 103 & \multirow[t]{4}{*}{$0.63^{* * *}$} & \multirow[t]{4}{*}{$2.00^{* * *}$} & \multirow[t]{4}{*}{$0.50(0.35,0.64)$} \\
\hline & & $\mathrm{L}$ & $81.4 \pm 2.9$ & 75 & 88 & & & \\
\hline & \multirow[t]{2}{*}{2003} & $\mathrm{E}$ & $82.9 \pm 1.5$ & 77 & 87 & & & \\
\hline & & $\mathrm{L}$ & $76.0 \pm 1.0$ & 74 & 78 & & & \\
\hline \multirow[t]{4}{*}{ Female flowering (days after sowing) } & \multirow[t]{2}{*}{2002} & $\mathrm{E}$ & $97.8 \pm 2.3$ & 92 & 104 & \multirow[t]{4}{*}{$0.75^{* * *}$} & \multirow[t]{4}{*}{$2.50^{* * *}$} & \multirow[t]{4}{*}{$0.50(0.35,0.64)$} \\
\hline & & $\mathrm{L}$ & $83.3 \pm 3.2$ & 77 & 90 & & & \\
\hline & \multirow[t]{2}{*}{2003} & $\mathrm{E}$ & $84.8 \pm 1.6$ & 80 & 89 & & & \\
\hline & & $\mathrm{L}$ & $77.5 \pm 1.2$ & 75 & 80 & & & \\
\hline \multirow[t]{4}{*}{ Plant height $(\mathrm{cm})$} & \multirow[t]{2}{*}{2002} & $\mathrm{E}$ & $207.5 \pm 16.7$ & 166 & 249 & \multirow[t]{4}{*}{$144.3^{* * *}$} & \multirow[t]{4}{*}{$21.5^{* * *}$} & \multirow[t]{4}{*}{$0.87(0.82,0.90)$} \\
\hline & & $\mathrm{L}$ & $212.6 \pm 16.1$ & 171 & 251 & & & \\
\hline & \multirow[t]{2}{*}{2003} & $\mathrm{E}$ & $199.7 \pm 18.0$ & 149 & 245 & & & \\
\hline & & $\mathrm{L}$ & $214.7 \pm 19.1$ & 167 & 257 & & & \\
\hline \multirow[t]{4}{*}{ Shoot dry weight (g plant ${ }^{-1}$ ) } & \multirow[t]{2}{*}{2002} & $\mathrm{E}$ & $148.7 \pm 25.0$ & 87 & 250 & \multirow[t]{4}{*}{$163.3^{* * *}$} & \multirow[t]{4}{*}{$41.0^{*}$} & \multirow[t]{4}{*}{$0.64(0.54,0.75)$} \\
\hline & & $\mathrm{L}$ & $119.0 \pm 20.5$ & 48 & 189 & & & \\
\hline & \multirow[t]{2}{*}{2003} & $\mathrm{E}$ & $147.0 \pm 24.9$ & 72 & 245 & & & \\
\hline & & $\mathrm{L}$ & $153.1 \pm 41.6$ & 68 & 391 & & & \\
\hline \multirow[t]{4}{*}{ Straw dry weight $\left(\mathrm{g} \mathrm{plant}^{-1}\right.$ ) } & \multirow[t]{2}{*}{2002} & $\mathrm{E}$ & $74.6 \pm 15.0$ & 26 & 142 & \multirow[t]{4}{*}{$68.8^{* * *}$} & \multirow[t]{4}{*}{$4.0^{\mathrm{ns}}$} & \multirow[t]{4}{*}{$0.75(0.68,0.82)$} \\
\hline & & $\mathrm{L}$ & $61.3 \pm 12.3$ & 24 & 119 & & & \\
\hline & \multirow[t]{2}{*}{2003} & $\mathrm{E}$ & $80.5 \pm 17.4$ & 35 & 155 & & & \\
\hline & & $\mathrm{L}$ & $82.6 \pm 17.1$ & 34 & 187 & & & \\
\hline \multirow[t]{4}{*}{ Ear dry weight (g plant ${ }^{-1}$ ) } & \multirow[t]{2}{*}{2002} & $\mathrm{E}$ & $74.1 \pm 14.5$ & 36 & 151 & $36.5^{* * *}$ & $28.5^{* *}$ & $0.50(0.35,0.64)$ \\
\hline & & $\mathrm{L}$ & $57.7 \pm 12.2$ & 21 & 98 & & & \\
\hline & 2003 & $\mathrm{E}$ & $66.3 \pm 12.4$ & 15 & 156 & & & \\
\hline & & $\mathrm{L}$ & $70.5 \pm 27.0$ & 20 & 204 & & & \\
\hline
\end{tabular}

Env. Environment, $E$ Early sowing, $L$ Late sowing, $S D$ Standard deviation, $N S$ non-significant difference

* Significance difference at $P<0.05 ;{ }^{* *}$ significance difference at $P<0.01 ;{ }^{* * *}$ significance difference at $P<0.001$

dry weight at harvest in the late-sown plants in 2002 and the early-sown plants in 2003. At this locus, the additivity of all QTLs was negative, meaning that the favorable allele was inherited from the chilling sensitive parent ETH-DL3.

\section{Discussion}

The biomass accumulation of maize plants was strongly affected by the climatic conditions during growth. In 2002, which was characterized by lower temperatures than 2003, seeds of late-sown plants were not fully mature (physiological maturity) before the first frost. Consequently, the biomass accumulation was lower in the late-sown set compared with the early-sown plants. Another factor, which influenced the biomass accumulation, was the time of flowering. Co-localizations of QTLs for ear and straw dry matter with QTLs for the date of flowering were found. The signs of additivity clearly demonstrated that, as it can be expected, late flowering was beneficial for a higher biomass due to a longer vegetative growth. Similarly, Moreau et al. (2004) frequently found co-localizations of silking date and grain yield in a maize $F_{3: 4}$ population grown under a large range of environmental conditions. However, other QTLs for flowering dates were associated with QTLs for plant height but not with QTLs for dry matter; some QTLs for flowering dates did not show any pleiotropic effect. This observation indicates that late flowering does not directly cause higher biomass, rather it seems that both traits can be independently controlled by the same gene or genomic region.

The main focus of this study was to answer the question whether a good chilling tolerance during seedling stage has a beneficial effect on the biomass at harvest. A significant correlation between grain yield and dry weight of seedlings, which were exposed to low temperature, was found in a set of maize inbred lines (Mock and McNeill 1979). However, results of Revilla et al. (2000) indicated that significant differences among hybrids for early vigor under low temperature conditions were not correlated with grain yield. The comparative analysis of QTLs identified in seedlings grown under chilling conditions in the field (Jompuk et al. 


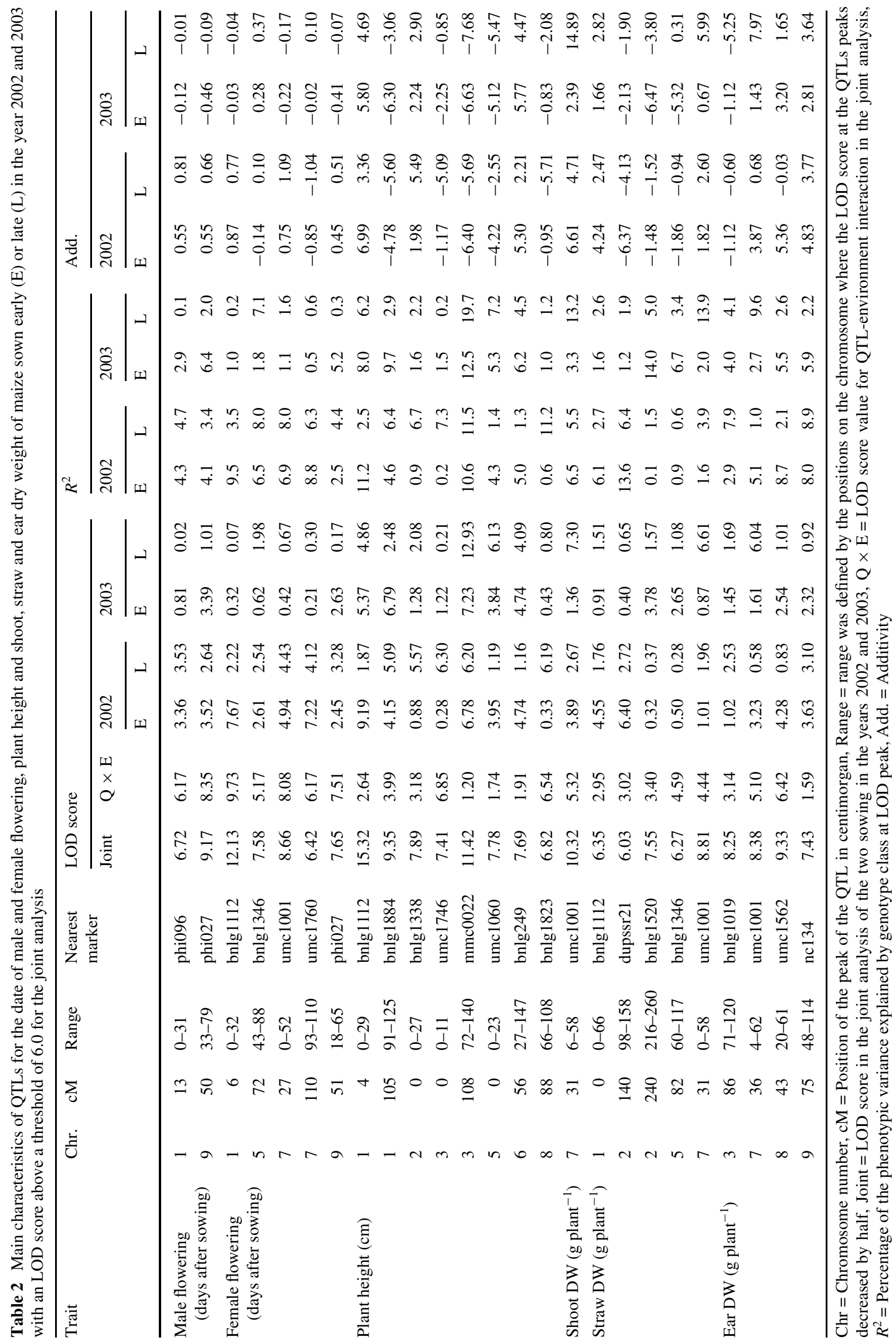


Fig. 2 Position of QTLs along the 10 maize chromosomes (C1-C10) for operating quantum efficiency of PSII ( $\left.\phi_{\text {PSII }}\right)$, leaf greenness (SPAD), maximum quantum efficiency of PSII primary photochemistry $\left(F_{\mathrm{v}} / F_{\mathrm{m}}\right)$ and shoot dry weight $\left(\mathrm{shDW}_{\mathrm{s}}\right)$ at the seedling stage (Jompuk et al. 2005) as compared to QTLs for straw (stDW), ear (eDW) and shoot dry weight (shDW) determined at harvest. Data were obtained from the single environment analysis

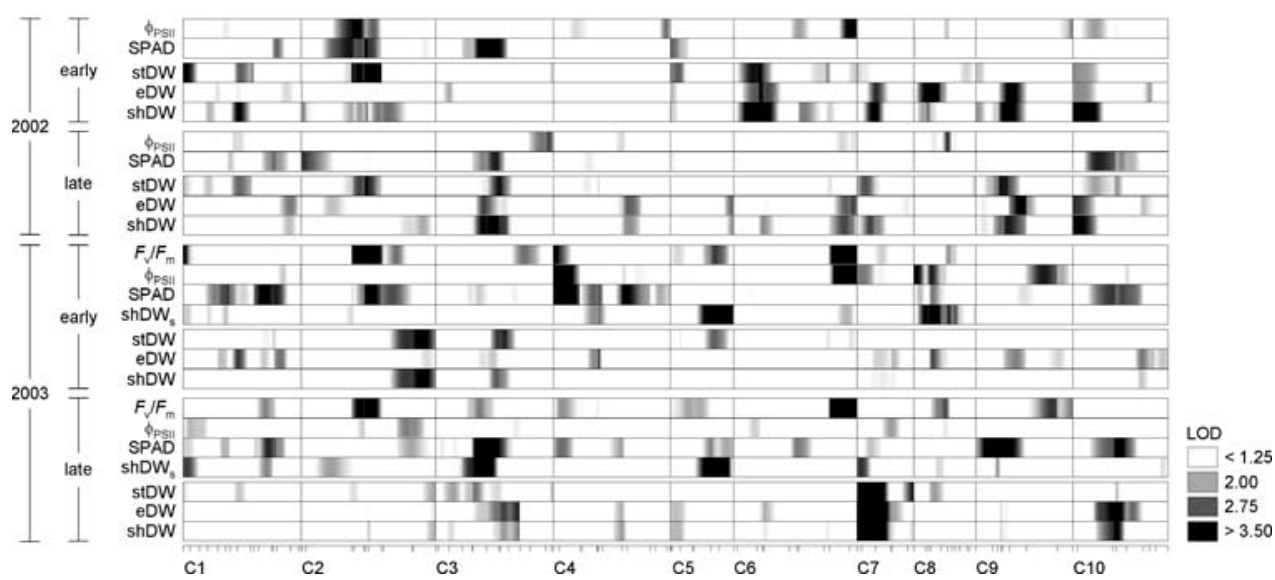

2005) with the QTLs found at harvest indicated that photosynthesis-related traits and morpho-physiological traits, like shoot dry weight, area of the third leaf, carbon and nitrogen concentration and $\mathrm{C}: \mathrm{N}$ ratio, at seedling stage did not result in an increased biomass at harvest. Concerning two of the overlapping QTLs it even seems that higher leaf greenness and higher photosynthetic efficiency had a negative effect on the final biomass. What is the reason of this poor relationship between chilling tolerance of the seedling and the final biomass? The analysis of the QTL on chromosome 3 might shed some light on this question. In the immediate vicinity of marker $m m c 0022$, a QTL was found for plant height and for ear dry weight. The position of this QTL was co-localized with a QTL for photosynthesisrelated traits detected in the late-sown plants of the mapping population at the seedling stage (Jompuk et al. 2005). This QTL was also found in seedlings grown at $25^{\circ} \mathrm{C}$ in growth chambers (Fracheboud et al. 2004). At the seedling stage too, the allele for good photosynthetic performance under warm conditions was inherited from the chilling-sensitive parent. This observation indicates that a good photosynthetic performance under optimal conditions increases yield. The mentioned chromosomal region of chromosome 3 harbored also a QTL for the area of the third leaf (Jompuk et al. 2005), those sign of additivity revealed that the higher photosynthetic activity was associated with a smaller leaf area at this locus. Since at this position no QTL with contrasting additivity was found for photosynthetic performance under chilling conditions, high photosynthesis under warm conditions seems not to have a drawback on the photosynthesis in the cold.

Another reason for the poor correlation between QTLs at maturity and QTLs for chilling tolerance at seedling stage might be the weather conditions during the later plant development which might have a predominant effect. In the year 2002, a hail storm during June drastically diminished the leaf area of the maize plants. Plants with a better early growth were at least as strongly affected as plants with a poor early vigor with respect to the loss of leaf area. The rest of the growing season in 2002 was characterized by rather low temperatures. The QTLs, which were found for yield-related traits solely in 2002, were potentially involved in the late-cold tolerance. Since the genetic control of cold tolerance seems to be independent at different growth stages (Revilla et al. 2000) it might explain why these QTLs were not co-localized with QTLs for cold tolerance of photosynthesis at seedling stage.

The year 2003 was characterized by severe drought stress and, therefore, this stress factor might have had a stronger effect on the yield than the chilling stress during seedling establishment. For the early sown set in 2003, plants of the $F_{2: 3}$ population segregated in leaf rolling which is a good indicator for the severity of the drought stress (Bänziger et al. 2000). Two QTLs were found for this trait, on chromosomes $1(79 \mathrm{cM}, \mathrm{LOD}=5.17)$ and 3 $(108 \mathrm{cM}, \mathrm{LOD}=4.05)$. In both cases, there was a pleiotropic effect on plant height, which was characterized by a contrasting additivity, meaning that tall plants suffered less from drought stress than short ones did. A positive relationship between root length and plant height was found i.e. during root selection in hybrid maize breeding (Rady 1996). Since no co-localization of QTLs for leaf rolling and for ear dry weight were found it seems less likely that genotypic differences in drought tolerance, which might be due to differences on rooting depth, had an influence on the yield in the year 2003 .

In conclusion, the QTL analysis revealed that high chilling tolerance of photosynthesis at the seedling stage did not have a large effect on the later yield of the maize mapping population in our study. Other morpho-physiological traits, which in addition described the seedling vigor such as seedling shoot dry weight, leaf area and nitrogen concentration, did not give clues on the later biomass accumulation as well. The present results indicate that the performance of the seedlings under chilling conditions in respect to photosynthesis and growth may not have a large effect on the 
biomass accumulation during later growth stages. The capacity of compensation in maize seems to be high, and the conditions during later growth phases might be more determining for biomass accumulation. This is in accordance with the earlier studies indicating that flowering and early seed development are the critical developmental period for determining maize grain yield (Classen and Shaw 1970; Shaw 1988). Although, an effect of early vigor on grain yield seems to depend largely on later growth conditions, a sufficient chilling tolerance of the maize seedling is beneficial, because of an improved capability of seedling to compete with weeds and to avoid fungal infection (Messiaen et al. 1976, 1977), and a lower risk of soil erosion and nitrate leaching.

\section{References}

Bänziger M, Edmeades GO, Beck D, Bellon M (2000) Breeding for drought and nitrogen stress tolerance in maize: from theory to practice. CIMMYT, Mexico DF

Basten CJ, Weir BS, Zeng Z-B (1994) Zmap-a QTL cartographer. In: Smith C, Gavora JS, Chesnais BBJ, Fairfull W, Gibson JP, Kennedy BW, Burnside EB (eds) Production: computing strategies and software, vol 22. Organizing Committee, 5th World Congress on Genetics Applied to Livestock Production. Guelph, pp 65-66

Basten CJ, Weir BS, Zeng Z-B (2005) QTL cartographer; a reference manual and tutorial for QTL mapping. Department of Statistics, North Carolina State University, Raleigh

Chenu K, Fournier C, Andrieu B, Giauffret C (2007) An architectural approach to investigate maize response to low temperature. In: Spiertz JHJ, Struik PC, Can Laar HH (eds) Scale and complexity in plant systems research: Gene-plant-crop relations. Springer, Heidelberg, pp 203-212

Classen MM, Shaw RH (1970) Water-deficit effects on corn. II. Grain components. Agron J 62:652-655

Dale AE, Drennan DSH (1997) Transplanted maize (Zea mays) for grain production in southern England. 1. Effects of planting date, transplant age at planting and cultivar on grain yield. J Agric Sci $128: 27-35$

Dolstra O, Jongmans MA, de Jong K (1988) Improvement and significance of resistance to low-temperature damage in maize (Zea mays L.). I. Chlorosis resistance. Euphytica 39:117-123

Fracheboud Y, Haldimann P, Leipner J, Stamp P (1999) Chlorophyll fluorescence as a selection tool for cold tolerance of photosynthesis in maize (Zea mays L.). J Exp Bot 50:1533-1540

Fracheboud Y, Ribaut J-M, Vargas M, Messmer R, Stamp P (2002) Identification of quantitative trait loci for cold tolerance of photosynthesis in maize (Zea mays L.). J Exp Bot 53:1967-1977

Fracheboud Y, Jompuk C, Ribaut J-M, Stamp P, Leipner J (2004) Genetic analysis of cold tolerance of photosynthesis in maize. Plant Mol Biol 56:241-253

Greaves JA (1996) Improving suboptimal temperature tolerance in maize - the search for variation. J Exp Bot 47:307-323

Hall AJ, Lemcoff JH, Trapani N (1981) Water stress before and during flowering in maize and its effect on yield, its components, and their determinants. Maydica 26:19-38

Hallauer AR, Miranda JB (1981) Quantitative genetics in maize breeding. Iowa State University Press, Ames
Hund A, Frascaroli E, Leipner J, Jompuk C, Stamp P, Fracheboud Y (2005) Cold tolerance of the photosynthetic apparatus: pleiotropic relationship between photosynthetic performance and specific leaf area of maize seedlings. Mol Breed 16:321-331

Jiang C, Zeng Z-B (1995) Multiple trait analysis of genetic mapping for quantitative trait loci. Genetics 140:1111-1127

Jompuk C, Fracheboud Y, Stamp P, Leipner J (2005) Mapping of quantitative trait loci associated with chilling tolerance in maize (Zea mays L.) seedlings grown under field conditions. J Exp Bot 56:1165-1175

Knapp SJ, Stroup WW, Ross WM (1985) Exact confidence intervals for heritability on a progeny mean basis. Crop Sci 25:192-194

Leipner J, Fracheboud Y, Stamp P (1999) Effect of growing season on the photosynthetic apparatus and leaf antioxidative defenses in two maize genotypes of different chilling tolerance. Environ Exp Bot 42:129-139

Messiaen CM, Belliard-Alonzo L, Barriére Y, de la Tullaye B (1976) Étude qualitative Fusarium roseum dans des sols des environs de Versailles sous diverses rotations et associations végétales. Ann Phytophathol 8:269-281

Messiaen CM, Barriére Y, Belliard-Alonzo L, de la Tullaye B, Bouhot D (1977) Étude qualitative Pythium dans quelques sols des environs de Versailles. Ann Phytophathol 9:455-465

Mock JJ, McNeill MJ (1979) Cold tolerance of maize inbred lines adapted to various latitudes in North America. Crop Sci 19:239-242

Moreau L, Charcosset A, Gallais A (2004) Use of trial clustering to study QTL $\times$ environment effects for grain yield and related traits in maize. Theor Appl Genet 110:92-105

Otegui ME, Bonhomme R (1998) Grain yield components in maize. I. Ear growth and kernel set. Field Crops Res 56:247-256

Patterson HD, Williams ER (1976) A new class of resolvable incomplete block designs. Biometrika 63:83-92

Pimentel C, Davey PA, Juvik JA, Long SP (2005) Gene loci in maize influencing susceptibility to chilling dependent photoinhibition of photosynthesis. Photosynth Res 85:319-326

Presterl T, Ouzunova M, Schmidt W, Möller EM, Röber FK, Knaak C, Ernst K, Westhoff P, Geiger HH (2007) Quantitative trait loci for early plant vigour of maize grown in chilly environments. Theor Appl Genet 114:1059-1070

Rady F (1996) Application of root selection in hybrid maize breeding. Novenytermeles 45:219-235

Rebourg C, Chastanet M, Gouesnard B, Weckler C, Dubreuil P, Charcosset A (2003) Maize introduction into Europe: the history reviewed in the light of molecular data. Theor Appl Genet 106:895-903

Revilla P, Malvar RA, Cartea ME, Butrón A, Ordás A (2000) Inheritance of cold tolerance at emergence and during early season growth in maize. Crop Sci 40:1579-1585

Revilla P, Soengas P, Cartea ME, Malvar RA, Ordás A (2003) Isozyme variability among European maize populations and the introduction of maize in Europe. Maydica 48:141-152

Richner W, Soldati A, Stamp P (1996) Shoot to root relations in fieldgrown maize seedlings. Agron J 88:56-61

Shaw RH (1988) Climate requirement In: Spraque GF, Dudley JW (eds) Corn and corn improvement, 3rd edn. ASA, Madison, pp 609-638

Stamp P (1986) Chilling stress in maize In: Dolstra O, Miedema P (eds) Breeding of silage maize. Proc. Eucarpia. Pudoc Wageningen, pp 43-50

Stirling CM, Nie G-Y, Aguilera C, Nugawela A, Long SP, Baker NR (1991) Photosynthetic productivity of an immature maize crop: changes in quantum yield of $\mathrm{CO}_{2}$ assimilation, conversion efficiency and thylakoid proteins. Plant Cell Environ 14:947-954

Vreugdenhil D, Koornneef M, Sergeeva LI (2007) Use of QTL analysis in physiological research. Russ J Plant Physiol 54:15-21 